\title{
RETURN TO FORT ROCK CAVE: ASSESSING THE SITE'S POTENTIAL TO CONTRIBUTE TO ONGOING DEBATES ABOUT HOW AND WHEN HUMANS COLONIZED THE GREAT BASIN
}

\author{
Thomas J. Connolly, Judson Byrd Finley, Geoffrey M. Smith, Dennis L. Jenkins, \\ Pamela E. Endzweig, Brian L. O’Neill, and Paul W. Baxter
}

\begin{abstract}
Oregon's Fort Rock Cave is iconic in respect to both the archaeology of the northern Great Basin and the history of debate about when the Great Basin was colonized. In 1938, Luther Cressman recovered dozens of sagebrush bark sandals from beneath Mt. Mazama ash that were later radiocarbon dated to between 10,500 and 9350 cal B.P. In 1970, Stephen Bedwell reported finding lithic tools associated with a date of more than 15,000 cal B.P., a date dismissed as unreasonably old by most researchers. Now, with evidence of a nearly 15,000-year-old occupation at the nearby Paisley Five Mile Point Caves, we returned to Fort Rock Cave to evaluate the validity of Bedwell's claim, assess the stratigraphic integrity of remaining deposits, and determine the potential for future work at the site. Here, we report the results of additional fieldwork at Fort Rock Cave undertaken in 2015 and 2016, which supports the early Holocene occupation, but does not confirm a pre-10,500 cal B.P. human presence.
\end{abstract}

La cueva de Fort Rock en Oregón es icónica por lo que representa para la arqueología de la parte norte de la Gran Cuenca y para la historia del debate sobre la primera ocupación de la Gran Cuenca. En 1938, Luther Cressman recuperó docenas de sandalias de corteza de artemisa debajo de una capa de cenizas del monte Mazama que fueron posteriormente fechadas por radiocarbono entre 10,500 y 9200 cal a.P. En 1970, Stephen Bedwell reportó haber encontrado herramientas líticas en asociación con una fecha de más de 15,000 cal. a.P., una fecha descartada como irrazonablemente antigua por la mayoría de los investigadores. Ahora, con evidencia de una ocupación de casi 15,000 años de antigüedad en las cercanas cinco cuevas de Paisley Five Mile Point, regresamos a la cueva de Fort Rock para evaluar la validez de las afirmaciones de Bedwell, evaluar la integridad estratigráfica de los depósitos restantes y determinar el potencial para investigaciones futuras en el lugar. Aquí presentamos los resultados de trabajo adicional en la cueva de Fort Rock llevado a cabo en 2015 y 2016. Estos apoyan la ocupación en el Holoceno temprano, pero no confirman una presencia humana antes de 10,500 cal a.P.

$\mathrm{F}$ ort Rock Cave holds an iconic position in the archaeological history of the northern Great Basin and in the debate surrounding when people first colonized the Desert West. Artifacts recovered during the site's initial excavation demonstrated that humans first occupied the Great Basin during the early Holocene
(Arnold and Libby 1951; Cressman 1951), and later work raised the possibility that people first visited Fort Rock Cave as early as $\sim 15,000 \mathrm{cal}$ B.P. (Bedwell 1970, 1973), two millennia before the Clovis era (Waters and Stafford 2007). That claim remains unconfirmed due to poor reporting standards and an undemonstrated association

\footnotetext{
Thomas J. Connolly — University of Oregon Museum of Natural and Cultural History, 1680 E. 15th Ave., Eugene, OR 97403, USA (connolly@uoregon.edu, corresponding author) Judson Byrd Finley Department of Sociology, Social Work, and Anthropology, Utah State University, 730 Old Main Hill, Logan, UT 84322-0730, USA (judson.finley@usu.edu)

Geoffrey M. Smith $\square$ Great Basin Paleoindian Research Unit, Department of Anthropology, University of Nevada, Reno, 1664 N. Virginia St, Reno, NV 89557, USA (geoffreys@unr.edu)

Dennis L. Jenkins, Pamela E. Endzweig, Brian L. O’Neill, and Paul W. Baxter $\square$ University of Oregon Museum of Natural and Cultural History, 1680 E. 15th Ave., Eugene, OR 97403, USA (djenkins@uoregon.edu; endzweig@uoregon.edu; boneill@uoregon.edu; pbaxter@uoregon.edu)
} 
between artifacts and dated charcoal. As such, most archaeologists dismiss the site in the preClovis debate (Beck and Jones 1997; Fiedel 2000; Haynes 1992; Hockett et al. 2008). Recent work at the nearby Paisley Five Mile Point Caves demonstrates that people occupied the northern Great Basin by at least $\sim 14,500$ cal B.P. (Gilbert et al. 2008; Jenkins et al. 2012, 2013), suggesting that although Bedwell's (1973) claim of a roughly contemporary occupation at Fort Rock Cave remains undemonstrated, it should not necessarily be dismissed outright. Work at the Paisley Caves has also highlighted the utility of returning to old sites in search of new data. In this paper, we focus on both issues: (1) evaluating the claim for pre-Clovis occupation of Fort Rock Cave, and its remaining potential for contributing to ongoing debates about how and when the New World was colonized; and (2) the prospects and problems that previously excavated sites offer to researchers seeking new answers to old questions.

\section{History of Work at Fort Rock Cave}

In 1937, amateur archaeologist Walt Perry excavated three small test pits in Fort Rock Cave. In a letter to University of Oregon archaeologist Luther Cressman, he reported finding "cracked and calcined bones and obsidian flakes" (Perry 1937:2). In 1938, Cressman led a crew from the university to work at Catlow, Paisley, and Fort Rock caves. At Fort Rock Cave, the crew excavated $\sim 55 \mathrm{~m}^{2}$ in just nine days, but recovered artifacts later recognized as Western Stemmed Tradition (WST) points and dozens of sagebrush bark sandals below what we now know as Mt. Mazama ash (Figures 1-3).

At the time of the discovery, the origin and age of the tephra was unknown, but Cressman claimed that artifacts found below it possessed great antiquity, a claim dismissed by many of his contemporaries (e.g., Krieger 1944; Roberts 1940; Steward 1940). Steward (1940) asserted that basketry from the Oregon caves demonstrated contemporaneity with the Basketmaker Culture (ca. 1500-3500 cal B.P.) in the American Southwest, while Roberts (1940) argued that the volcanic ash was deposited within only the last 1,000 years. Martin and colleagues (1947:228) proclaimed in their overview of North American archaeology, Indians before Columbus, that the southeastern Oregon culture "is probably not more than two thousand years old." With the advent of radiocarbon dating in 1950, Cressman submitted sandals from Fort Rock Cave to the University of Chicago for dating. When averaged, two radiocarbon dates produced an age of $9053 \pm 350$ B.P. $\left(9436-11,211\right.$ cal B.P.). ${ }^{1}$ As a result, Arnold and Libby (1951:117) declared the Fort Rock sandals to be the "oldest artifacts measured in the Americas," and vindicated Cressman's claim for an early occupation of the region. Today, the Fort Rock sandals remain the earliest directly dated footwear in the world, and Fort Rock-style sandals have been directly dated to the terminal Pleistocene/early Holocene (TP/EH) at nine other northwestern Great Basin sites (Connolly et al. 2016; Ollivier 2016). Because of the early age of the wellcrafted footwear and the site's role in the debate surrounding the colonization of the far west, Fort Rock Cave was designated a National Historic Landmark in 1961 and listed on the National Register of Historic Places in 1966.

In 1966 and 1967, Cressman's student Stephen Bedwell returned to Fort Rock Cave to secure additional datable material (Bedwell and Cressman 1971; Cressman 1988). In the three decades following Cressman's excavations, the site witnessed rampant looting, and by the time of Bedwell's return, the cave's interior was largely cleaned out. A rancher had mechanically removed some deposits to provide better shelter for livestock; after manure in the cave caught fire and burned for an extended period, he extinguished the fire by flooding the cave and removing the manure with a tractor (Kittleman 1968). Today, staining on the cave walls well above the current floor marks the original position of the top of the cave's deposits (Figure 4).

When Bedwell returned in 1966, he focused most of his efforts inside the cave, where he failed to identify intact deposits (and, in fact, did not bother to catalog artifacts from the interior units that he thought were stratigraphically unreliable). The following year, he located undisturbed deposits just outside the cave's mouth, where he radiocarbon-dated four charcoal samples from a stratigraphic column in Square 10 (Table 1; see 


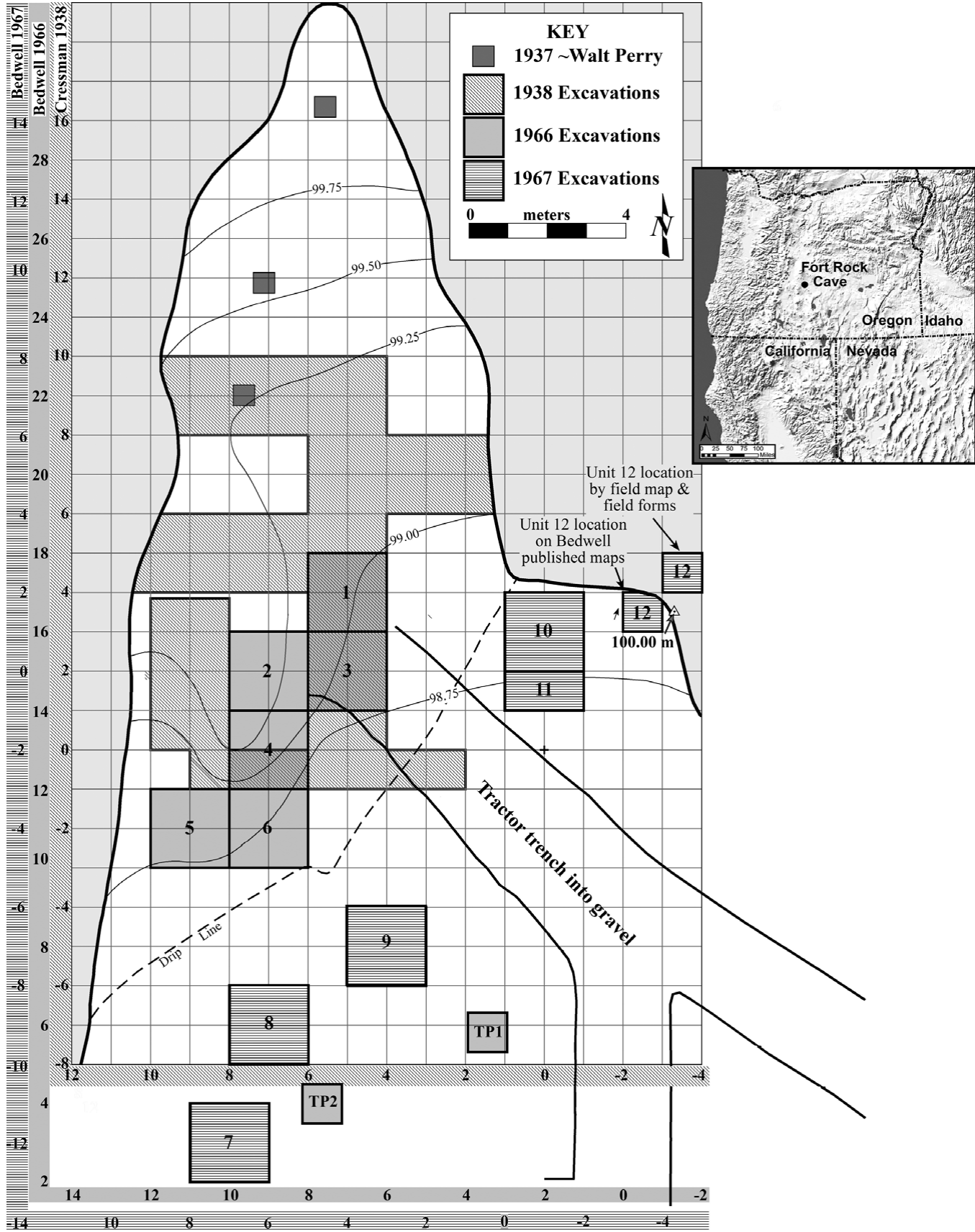

Figure 1. Plan view of Fort Rock Cave showing the different grid systems and locations of excavations during the 1938, 1966, and 1967 field seasons.

Figure 1). The dates were in proper stratigraphic order, and the deepest sample, purportedly collected from atop Pleistocene lake gravels, possesses a calibrated midpoint of more than 15,000 cal B.P. Bedwell (1973) claimed that artifacts, including a mano, several scrapers, and a WST projectile point, were closely associated with the radiocarbon sample. 


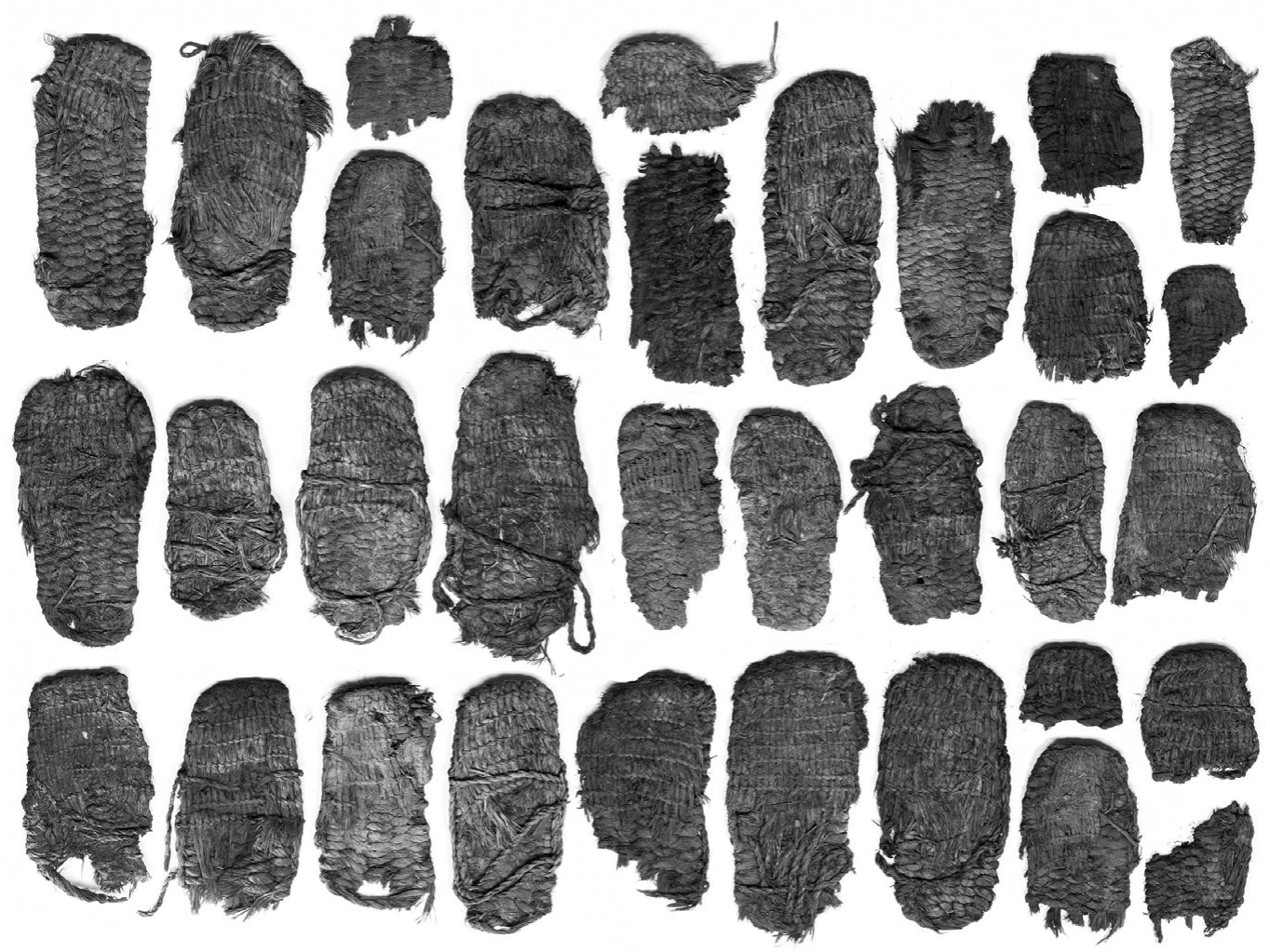

Figure 2. A selection of Fort Rock Cave twined sandals of pre-Mazama age, made of sagebrush bark (Brian Lanker photo, courtesy the University of Oregon Museum of Natural \& Cultural History).

As they had with Cressman's claims, researchers dismissed Bedwell's early date as too old and questioned the association between the artifacts and the dated charcoal (Beck and Jones 1997; Fiedel 2000; Haynes 1992; Hockett et al. 2008). Unfortunately, such questions remain unresolved because neither Cressman nor Bedwell fully reported their work at the site. Field notes, profile drawings, and photographs document their respective efforts, but they are not detailed enough to resolve long-standing questions about when Fort Rock Cave was initially occupied. Only additional fieldwork would hold the potential to do so, and with that goal in mind, we returned to Fort Rock Cave in 2015 and 2016. Our primary objectives were to document the site's remaining stratigraphy, assess the integrity of any remaining deposits, and, if possible, evaluate the context of Bedwell's earliest radiocarbon date. Here we present the results of those efforts.

\section{Materials and Methods}

A major obstacle in revisiting sites excavated long ago is reconstructing the original investigation. Cressman's (1938) and Bedwell's (19671968) notes indicate that the same grid system was at least approximated in 1938, 1966, and 1967, although a different coordinate system was apparently used each year. Unfortunately, we failed to locate any permanent datum marker that would enable us to reestablish their grid. In addition, we found significant discrepancies between field maps and published maps, creating uncertainty regarding the true locations of some excavation units and their relationships to one another. In light of these issues, we imposed yet another provenience grid on the site, set permanent datum markers, and established true elevations using a USGS benchmark located atop the nearby Fort Rock caldera (Figure 5). 
Table 1. Radiocarbon and OSL Dates from Fort Rock Cave.

\begin{tabular}{|c|c|c|c|c|c|}
\hline Lab Number & ${ }^{14} \mathrm{C}$ Age & $2 \sigma$ cal B.P. Range ${ }^{a}$ & Dated Material & Context & Reference \\
\hline \multicolumn{6}{|c|}{ Previously Reported Radiocarbon Dates } \\
\hline $\mathrm{C}-428 \mathrm{a}$ & $9188 \pm 480^{\mathrm{b}}$ & $9270-12,004$ & Sagebrush bark, Fort Rock-style sandal & & Arnold and Libby 1951:117 \\
\hline$C-429 b$ & $8916 \pm 540^{\mathrm{b}}$ & $8644-11,704$ & Sagebrush bark, Fort Rock-style sandal & & Cressman 1951:308 \\
\hline I-1917 & $8500 \pm 140$ & 9904-9124 & Sagebrush bark, Fort Rock-style sandal & & Bedwell and Cressman 1971:10 \\
\hline GaK-1738 & $13,200 \pm 720^{c}$ & $13,776-17,854$ & Unidentified charcoal & Level 10, Square 10, top of gravel & Bedwell 1973:35 \\
\hline GaK-2145 & $4450 \pm 100^{c}$ & $4845-5433$ & Unidentified charcoal & Level 4, Square 10 & Bedwell 1973:35 \\
\hline GaK-2146 & $8550 \pm 150^{c}$ & $9138-10,135$ & Unidentified charcoal & Level 6, Square 10 & Bedwell 1973:35 \\
\hline GaK-2147 & $10,200 \pm 230^{c}$ & $11,236-12,568$ & Unidentified charcoal & Level 8, Square 10 & Bedwell 1973:35 \\
\hline AA-101454 & $8384 \pm 49$ & $9285-9500$ & Sagebrush bark, Fort Rock-style sandal & & Connolly et al. 2016:497 \\
\hline AA-101455 & $8447 \pm 49$ & $9431-9540$ & Sagebrush bark, Fort Rock-style sandal & & Connolly et al. 2016:497 \\
\hline AA-19150 & $4430 \pm 60$ & $4866-5287$ & Tule, false embroidery, Catlow Twine basketry & & Connolly et al. 1998:89 \\
\hline AA-30060 & $6277 \pm 55$ & $7013-7318$ & Tule, open diagonal twine basketry, Z-weft & & Connolly et al. 2016:502 \\
\hline AA-9249 & $9215 \pm 140$ & $9945-11,059$ & Sagebrush bark, Fort Rock-style sandal & & Connolly and Cannon 1999:311 \\
\hline AA-9250 & $8715 \pm 105$ & $9530-10,151$ & Sagebrush bark, Fort Rock-style sandal & & Connolly and Cannon 1999:311 \\
\hline AA-99757 & $8281 \pm 54$ & $9092-9441$ & Tule, open twine basketry, double X-warp & & Connolly et al. 2016:502 \\
\hline UCIAMS-127300 & $8365 \pm 25$ & $9305-9468$ & Sagebrush bark, Fort Rock-style sandal & & Connolly et al. 2016:497 \\
\hline UCIAMS-127301 & $8450 \pm 25$ & $9441-9523$ & Sagebrush bark, Fort Rock-style sandal & & Connolly et al. 2016:497 \\
\hline UCIAMS-87419 & $8480 \pm 30$ & $9463-9534$ & Sagebrush bark, Fort Rock-style sandal & & Connolly et al. 2016:497 \\
\hline Beta-221343 & $8460 \pm 40$ & $9433-9532$ & Sagebrush bark, Fort Rock-style sandal & & Connolly et al. $2016: 497$ \\
\hline \multicolumn{6}{|c|}{ New Radiocarbon Dates } \\
\hline AA-9248 & $1920 \pm 75$ & $1633-2050$ & Tule, false embroidery, Catlow Twine basketry & & This paper \\
\hline Beta-419976 & $550 \pm 30$ & $517-639$ & Unidentified dicot twig & Top of Stratum G1, Unit 6 & This paper \\
\hline Beta-419977 & $8280 \pm 30$ & $9137-9405$ & Sagebrush twig & Base of Stratum G1, Unit 7 & This paper \\
\hline Beta-419978 & $1240 \pm 30$ & $1074-1266$ & Herbivore coprolite & Top of Stratum G1, Unit 7 & This paper \\
\hline Beta-440728 & $3270 \pm 30$ & $3409-3572$ & Sagebrush (?) bark & Feature 1, Level 10, Unit 15 & This paper \\
\hline Beta-440729 & Modern & $\mathrm{n} / \mathrm{a}$ & Charcoal & Unit C/19, Level 16 & This paper \\
\hline D-AMS-014508 & $321 \pm 27$ & $305-468$ & Herbivore coprolite & Top of Stratum G1, Unit 6 & This paper \\
\hline \multicolumn{6}{|l|}{ New OSL Dates } \\
\hline USU-2127 & $2820 \pm 850^{\mathrm{d}}$ & $1120-4550$ & Quartz Sand & Strata $\mathrm{G} / \mathrm{H}$ contact, Unit 3 & This paper \\
\hline
\end{tabular}



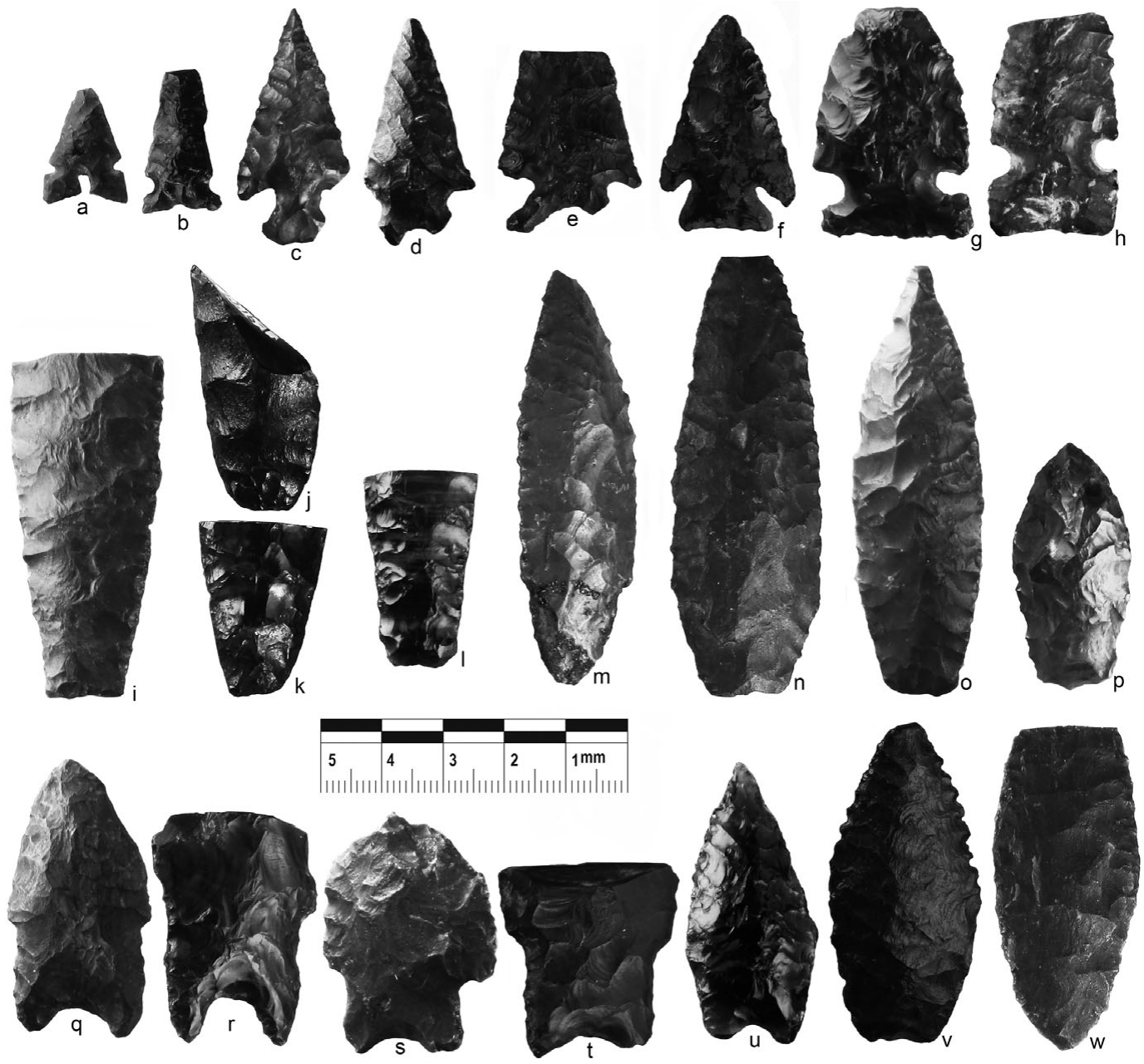

Figure 3. A selection of (a-h) post-Mazama and (i-w) pre-Mazama artifacts from Cressman's 1938 excavation, UOMNCH Accession 60: (a-b) Desert Side-notched; (c) Rosegate; (d-e) Elko Eared; (f) Elko Corner-notched; (gh) Northern Side-notched; (i-w) Western Stemmed Tradition (including Parman, Haskett, and Windust subtypes) and Cascade/Foliate points.

To assess the integrity of the remaining deposits, we excavated $7.25 \mathrm{~m}^{2}$ during two weeklong sessions. We excavated 18 probes inside and outside of the cave's dripline; most probes were $0.25 \mathrm{~m}^{2}$, but probes 13 and 15 inside the cave were $0.5 \times 1 \mathrm{~m}$ in size to provide more continuous stratigraphic exposures, and three outside the cave, where deeper deposits lie above the lake gravels, were expanded to $1 \mathrm{~m}^{2}$ units. We laid out probes 12,14 , and 18 initially, but in light of the extent of disturbance in adjacent units did not excavate them. We excavated in $5 \mathrm{~cm}$ levels measured from the current ground surface and started new levels when we noted stratigraphic changes. We sifted all sediment using one-eighth-inch screens and point-plotted diagnostic artifacts (e.g., projectile points) when recovered in situ. Previous researchers noted that the basal beach gravels were sterile. We excavated one unit, Probe 7 (Figure 6), approximately $50 \mathrm{~cm}$ into those sediments to verify this claim; doing so, we terminated other units after reaching the beach gravel contact. 


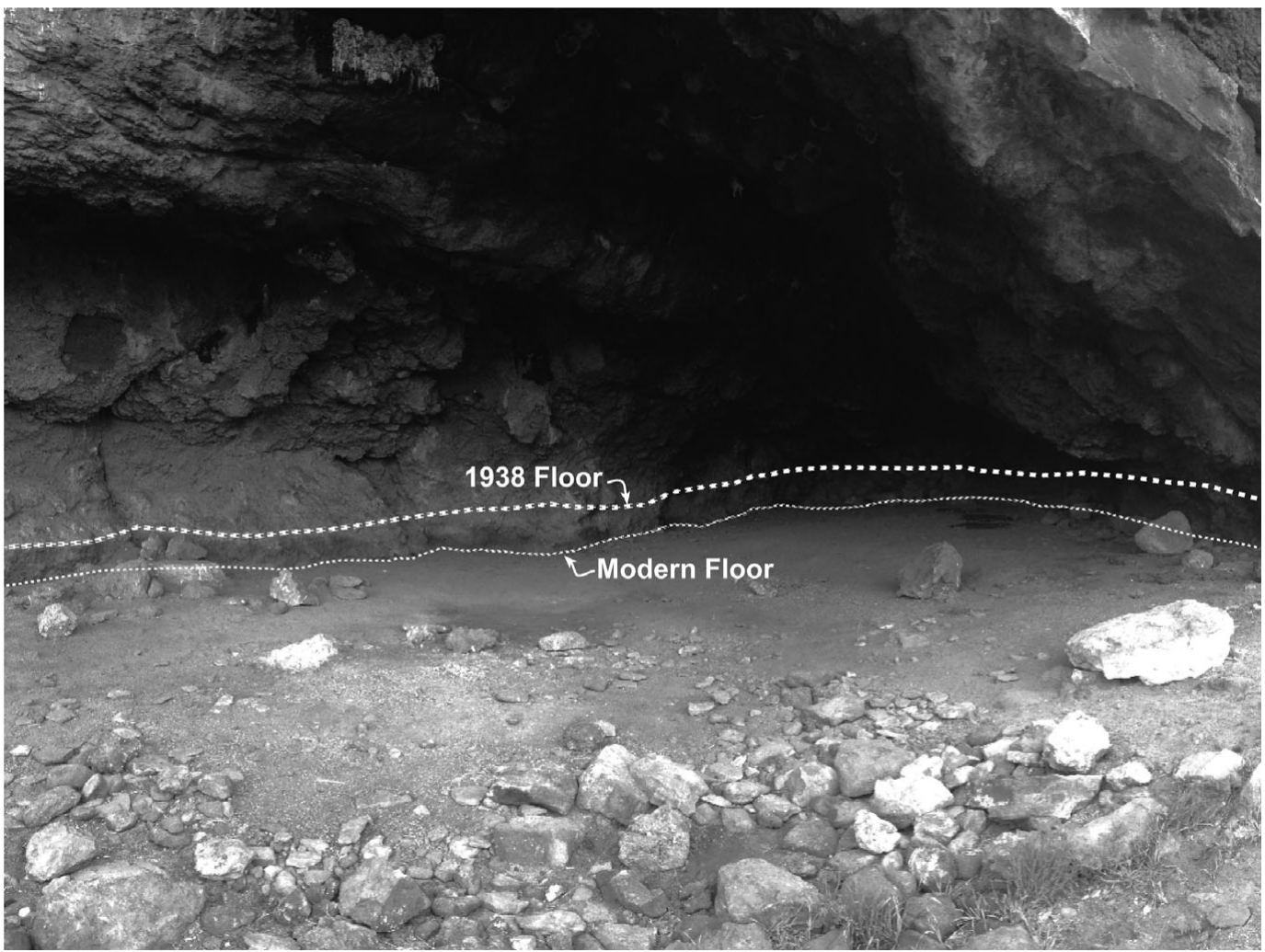

Figure 4. Interior of Fort Rock Cave today. The line on the wall indicates the approximate floor height when Cressman initially excavated in the cave in 1938.

\section{Results}

\section{Formation Processes}

Lake-Level History. Fort Rock Basin is near the northeastern margin of the Basin and Range physiographic province characterized by Tertiary extensional tectonics producing fault-block topography and closed basins that held Quaternary pluvial lakes (Freidel 1994; Lawrence 1976; Walker et al. 1967). Late Pliocene and Pleistocene volcanism built numerous volcanic cones and tuff rings, including the prominent landform of Fort Rock itself. Freidel (1994) identified five major Quaternary shorelines in the basin representing at least two major late Pleistocene lake cycles. No radiocarbon ages are available to determine when the lake reached its high stand at 1,384 m. Freidel (1994:31) hypothesized that this shoreline formed either sometime before 42,000 cal B.P. or during the Last Glacial
Maximum (LGM), when a high stand at the equivalent elevation in the adjacent Alkali Basin overflowed into the Fort Rock Basin, stabilizing the lake level there at $1,384 \mathrm{~m}$. Alternatively, the LGM flow from Alkali Basin may have stabilized Pluvial Lake Fort Rock at 1,367 m, the next highest shoreline. The most prominent shoreline in Fort Rock Basin is at 1,353-1,356 m, which formed the wave-cut Fort Rock Cave presumably between the LGM and approximately 15,000 cal B.P. It is unknown whether the $1,353-1,356 \mathrm{~m}$ shoreline formed as the result of either a single still stand or multiple lake-level changes stabilizing at this elevation (Freidel 1994:32). As the terminal Pleistocene approached, Pluvial Lake Fort Rock fell another $18 \mathrm{~m}$, stabilizing again at $1,332 \mathrm{~m}$. Lower shorelines in the basin provide evidence of a persistent lake well into the early and late Holocene (Allison 1979; Forbes 1973; Jenkins, Droz, and Connolly 2004). Besides formation of the wave-cut notch that is Fort 


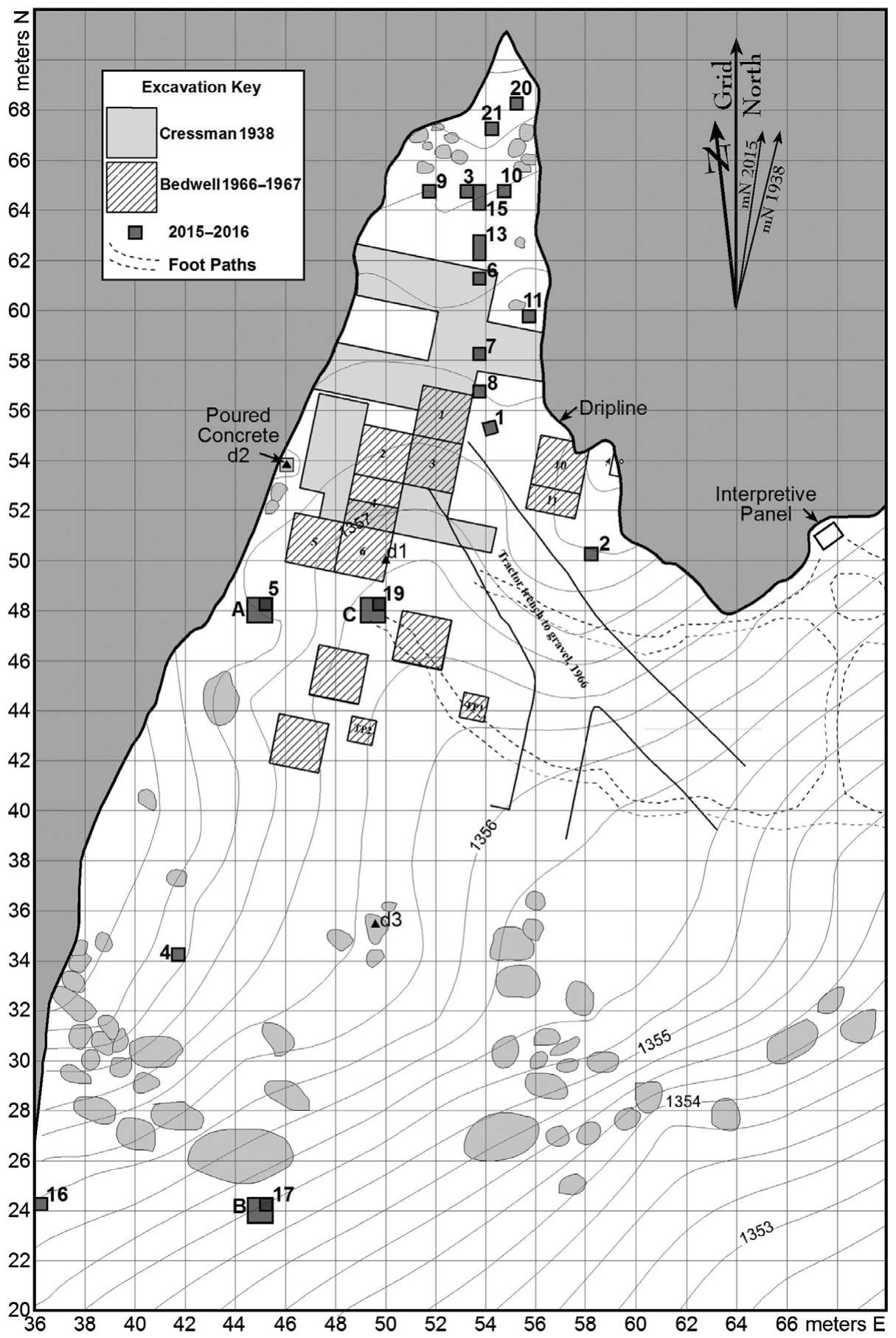

Figure 5. Locations of 2015 and 2016 test pits superimposed on a new site map that features absolute elevations inside Fort Rock Cave. 


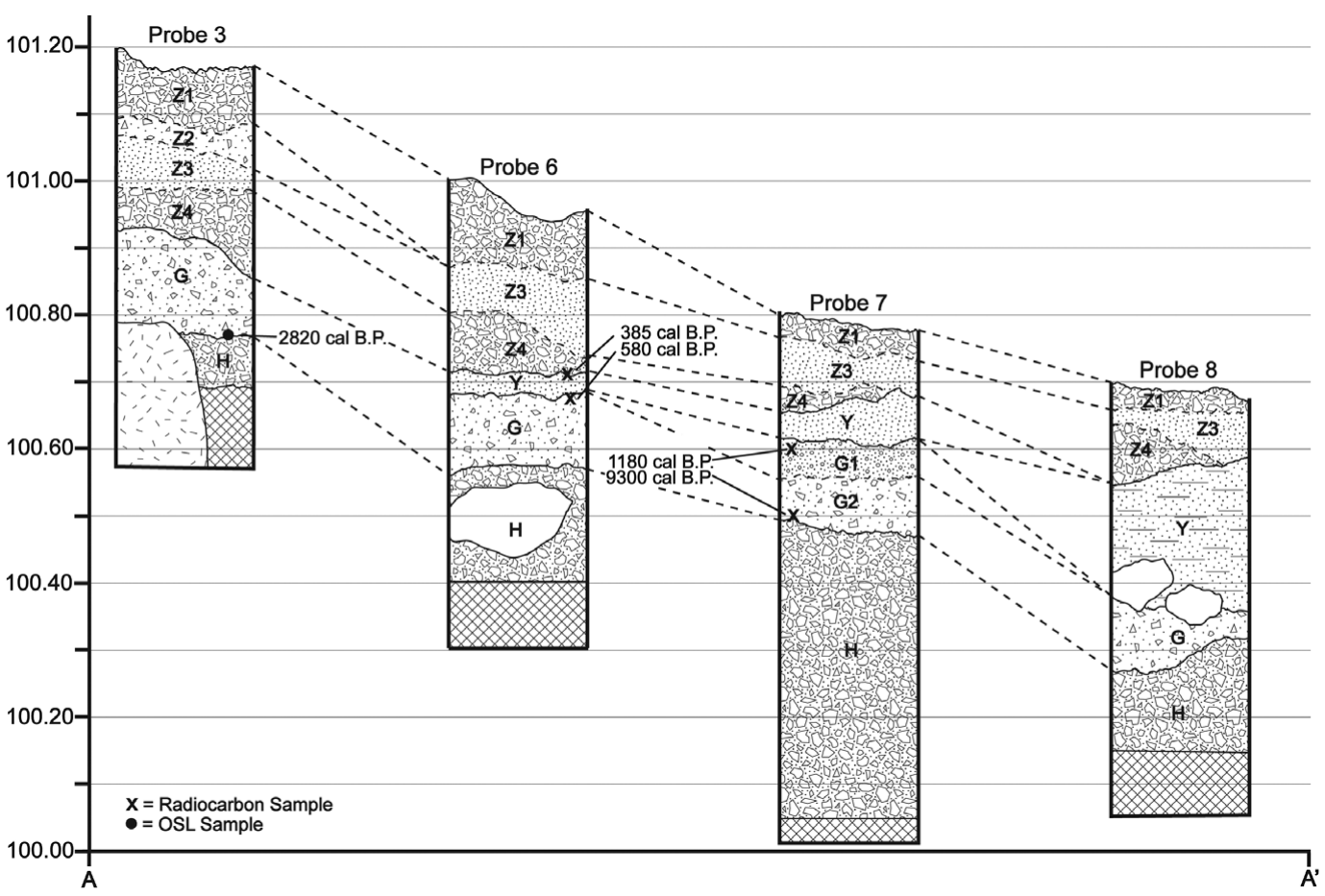

Figure 6. Stratigraphic fence diagram of Fort Rock Cave across a north-south cross-section.

Rock Cave, the 1,353-1,356 m and 1,332 m lake levels are critical sediment sources for the earliest geological and archaeological deposits.

Site Stratigraphy. Cressman (1942:25) and Cressman and Williams (1940) did not describe the site stratigraphy in detail, other than declaring that "like the Paisley Caves, [Fort Rock Cave] failed to show convincing stratigraphy." He simply distinguished "above pumice" (Mazama tephra) and "below pumice" assemblages. Based on Cressman's (1942:Figure 9) published schematic profile, it appears that the sub-Mazama occupation stratum is up to $45 \mathrm{~cm}$ thick near the central area of his excavation, tapering to thin lenses at the margins of his block. When Bedwell returned to reexamine the site in 1966, he failed to identify intact deposits in the cave's interior and focused the following year on areas outside of the cave's mouth. There he found that Cressman's occupation layer was thin and contained no preserved perishable artifacts. Importantly, Bedwell (1970:30) correlated this layer with a "cobble-filled brown silt observed below the pumice."
Both University of Oregon geologist Lawrence R. Kittleman (1968) and Bedwell (1973) provide descriptions of the site's stratigraphy. Kittleman (1968:2) divided the deposit into five depositional units including angular "talus and roof fall material" (Stratum I), two strata of lacustrine gravel (II and III), a "thin and discontinuous" silty sand (IV) that correlates with Cressman's (1942) occupation layer, and a post-Mazama sandy pumice $(\mathrm{V})$ that also contained artifacts. Bedwell's (1970:28) Square 10 profile, which he presented as "the typical stratigraphic picture" describes eight distinct strata labeled A through $\mathrm{H}$ in his field drawing. Strata $\mathrm{A}$ through $\mathrm{F}$ include various ash lenses, manure accumulations, surface dust, and pumiceous strata subsumed within Kittleman's Stratum V. Bedwell's Strata G and H correspond to Kittleman's strata III and II; his Square 10 profile did not recognize the discontinuous silty sand recorded by Kittleman (i.e., his Stratum IV) between the pumiceous sand and the Pleistocene gravels.

The primary objective of our project geoarchaeology was to systematically describe the 
remaining deposits and determine whether intact deposits remained to evaluate the likelihood of the pre-Clovis occupation. To maintain consistency with the original work, we followed Bedwell's (1970) stratigraphic descriptions (i.e., Latin letters A through $\mathrm{H}$ ) to the extent possible. Given uncertainties in the location of both Cressman's and Bedwell's excavations and the subsequent vandalism and other activities, the primary challenge was differentiating in situ deposits from backfill. We determined that the bulk of the extant deposits are in fact backfill, which we designated strata $\mathrm{Y}$ and $\mathrm{Z}$ to be consistent with the Latin letter designations but to avoid overlap with Bedwell's system (see Figure 6). Backfill consisted of unburned and burned cow manure (Stratum Z) and loose gravelly silt with a dominant component of sand- and granule-size pumice (Stratum Y) that is a mixture of preand post-Mazama sediments composed of wellrounded beach gravels, eolian silt, and Mazama pumice.

Our test excavations demonstrate that no deposits resembling Bedwell's strata A through $F$ remain intact within the cave interior. The bulk of the remaining deposits consist of two distinct strata that we are confident correlate with Bedwell's strata $G$ and H. Stratum G is silty gravel with clasts up to $10 \mathrm{~cm}$ in maximum diameter in a clast-supported framework. Stratum $\mathrm{H}$ is gravel with clasts reaching $25 \mathrm{~cm}$ in maximum diameter in an imbricated, clastsupported framework. Stratum H contains red and gray basalt clasts that both Bedwell (1970) and Kittleman (1968) described. The key properties differentiating strata $\mathrm{G}$ and $\mathrm{H}$ are the notably redder vesicular gravel in Stratum $\mathrm{H}$, and the fact that dark, yellowish-brown silt infiltrated voids between clasts in Stratum G while basalt coarse sand and granules filled voids in Stratum $\mathrm{H}$. We interpret Stratum $\mathrm{H}$ as a beach shingle of pluvial Lake Fort Rock deposited during the 1,3531,356 $\mathrm{m}$ stand still. Two working hypotheses explain deposition of Stratum G. First, Stratum $\mathrm{G}$ may be facies of the terminal Pleistocene beach gravel deposited during the same event as Stratum $\mathrm{H}$ but with a dominant postdepositional eolian component that originated from the nearby shoreline as the lake retreated to the $1,332 \mathrm{~m}$ elevation. Alternatively, and more likely, because of clast-size differences and the fact that Stratum $G$ lacks the diagnostic red vesicular gravels of Stratum H, Stratum G gravels may reflect a separate still stand from the one depositing Stratum H gravels. This explanation would be consistent with Freidel's (1994:32) hypothesis of multiple stand stills of Pluvial Lake Fort Rock at the 1,353-1,356 m elevation. Stratum $\mathrm{G}$ both inside and outside the shelter yielded a large volume of chipped stone debitage and highly processed animal bone (see below). The eolian silt and artifact assemblage were deposited after the gravel with both filtering into an open framework of the clast-supported gravel matrix.

\section{Site Chronology}

Site radiocarbon chronology prior to our work was based on seven dates from Cressman's (1951), Bedwell's (1970, 1973) and Bedwell and Cressman's (1971) work, and 12 direct AMS ages on sandals and basketry (Connolly et al. 2016; Table 1). We first reconsider the context of the controversial early dates Bedwell reported, all of which are from his Square 10 located just outside the cave's mouth. The ages are in apparent proper stratigraphic order (Level 4, ca. 5150 cal B.P.; Level 6, ca. 9650 cal B.P.; Level 8, ca. 11,900 cal B.P.), including the deepest one from the top of Pleistocene lake gravels (i.e., Stratum G) in Level 10, which calibrates to ca. 15,800 cal B.P.

We learned from field notes of crew members Stanley Bussey and Charles Rohrbaugh that both levels 4 and 6 were clearly within the pumiceous sand (likely Bedwell's Stratum D or F; Kittleman's Stratum V) derived from the Mt. Mazama eruption. In Level 6, Bussey (1967:18) recorded that "fill was the same as upper levels of this stratum-brown or yellowish-tan pumicy dirt." Clearly, Bedwell's age of $\sim 9650$ cal B.P. in a deposit consisting largely of redeposited pumice from the $\sim 7600$ cal B.P. Mt. Mazama eruption is erroneous. The excavators may have reached the base of the pumice stratum at the bottom of Level 8; they initially encountered an "increasing amount of rock," but the "amount of pumice is about the same" (Bussey 1967:20). Bussey (1967:22) states that by the end of the level, "pumice has dropped slightly in amount." Again, it is improbable that a date of nearly 12,000 
cal B.P. would be associated with the base of the Mazama unit or the immediate sub-Mazama surface. Cultural material and fragments of sagebrush bark increased in Level 9, which seems consistent with Cressman's occupation layer and from where numerous radiocarbon ages on sandals range from $\sim 10,500$ to $\sim 9350 \mathrm{cal}$ B.P. (Connolly et al. 2016). In Level 10, Bussey (1967:26) noted, "We are now in the silt covered cobble layer. ... Below the ash (mentioned above) was the first appearance of the pure silt found between the cobbles." Based on our observations, this is certainly Stratum G. The charcoal sample that produced the oldest age was "taken from ash lense [sic]" in this level (Bussey 1967:26). Bedwell (1970:26) reported the sample as being from "a fire area directly on top of the gravel in Square 10." Cressman (1977:146) later reported this as a "hearth," a term not used by either the excavators or Bedwell.

These interpretations as established from the original field notes collectively call into question the contextual reliability of Bedwell's (1970) Square 10 chronological sequence. Compounding the problem is the fact that the oldest ages have large errors, and are from the Gakushuin Laboratory, which produced erroneous dates, particularly in the 1960s and early 1970s on the Great Plains (Banks and Wigand 2005; Blakeslee 1994), Oceania (Clark and Anderson 2001; Spriggs 1990), and Alaska (Maschner 2004). Given the improbable context of the Fort Rock dates noted here, and problems with Gakushuin Laboratory dates, Bedwell's Square 10 sequence, including the 15,800 cal B.P. date, are likely unreliable.

2015-2016 Chronology. We obtained seven radiocarbon ages and one optically stimulated luminescence (OSL) date from our 2015-2016 fieldwork (see Table 1, Figure 6). Organic samples for radiocarbon analysis come from probes 6,7 , and 15 , located near the center of the cave. We noted some disturbance to the top of the gravel in Probe 7, and the integrity of the other gravel deposits was uncertain, but we obtained two samples from the top and bottom of Stratum G in each of probes 6 and 7. The young upper ages confirm disturbance at the top of the stratum in both units. While the young ages at the bottom of Stratum $G$ in probes 3 and 6 indicate a mixed deposit in this portion of the shelter interior, a date from the base of Stratum $G$ in Probe 7 is consistent with the main occupation associated with the sandals. We identified a pocket of charcoal-stained sediment (Feature 1) with some faunal material within Stratum $H$ in Unit 15 adjacent to Probe 3 (see Figure 5). A radiocarbon age of 3490 cal B.P. indicates a late Holocene disturbance into this terminal Pleistocene deposit.

To help establish an independent chronological control directly on the sediment deposition, we collected a single OSL sample from the Stratum G-H contact in Probe 3, which was located near the rear of the cave well north of previous excavations. Fort Rock Cave is not an ideal location for OSL dating due to the relatively young (i.e., Pleistocene) volcanic terrain that lacks suitable quartz or feldspar sands. While we made an effort to date single grains of quartz and small aliquots of feldspar, the final age estimate was based on 11 of 59 accepted small aliquots of quartz sand (Rittenour 2016; Table 2). The sample returned an age of $2820 \pm 850$ B.P., which is also clearly too young for the context and, like the mixed radiocarbon ages, indicates substantial disturbance in the rear of the cave.

Outside the cave, we excavated the $1 \mathrm{~m}^{2}$ Unit 5 down $\sim 70 \mathrm{~cm}$ through very loose pumice sand before encountering a $\sim 5 \mathrm{~cm}$ thick lens of pumice-free silt that we believe is pre-Mazama (> 7700 cal B.P.) in age (Figure 7). The lens overlaid and filtered down into underlying gray gravels. We documented a dramatic peak in lithic artifacts in the thin silt lens, which clearly corresponds to the silt lens that Kittleman (1968) correlated with Cressman's (1942) occupation layer. Unfortunately, we did not encounter any dateable material in Unit 5. In nearby Unit 19, located in front of the cave about $4 \mathrm{~m}$ east of Unit 5, Stratum G was partially disturbed; a charcoal sample taken near the Stratum G/H contact returned a modern age (Beta-440729).

\section{Lithic Artifacts and Faunal Remains}

Although the stratigraphic investigations at Fort Rock Cave were disappointing due to extensive disturbance over the years, we recovered a modest sample of lithic artifacts (mostly obsidian) 
Table 2. Optically Stimulated Luminescence (OSL) Date from Fort Rock Cave.

\begin{tabular}{lccccccc}
\hline $\begin{array}{l}\text { Sample } \\
\text { Number }\end{array}$ & $\begin{array}{c}\text { USU } \\
\text { Number }\end{array}$ & $\begin{array}{c}\text { Depth } \\
(\mathrm{m})\end{array}$ & $\begin{array}{c}\text { Number of } \\
\text { Aliquots }^{\mathrm{a}}\end{array}$ & $\begin{array}{c}\text { Dose Rate } \\
(\mathrm{Gy} / \mathrm{ka})\end{array}$ & $\begin{array}{c}\mathrm{D}_{\mathrm{E}}^{\mathrm{b}} \pm 2 \sigma \\
(\mathrm{Gy})\end{array}$ & $\begin{array}{c}\mathrm{OD}^{\mathrm{c}} \\
(\%)\end{array}$ & $\begin{array}{c}\text { OSL Age } \pm 2 \sigma \\
(\mathrm{ka})\end{array}$ \\
\hline 3-1 OSL & USU-2127 & 0.3 & $11(59)$ & $2.44 \pm 0.13$ & $6.88 \pm 1.93$ & 0.0 & $2.82 \pm 0.85$ \\
\hline
\end{tabular}

${ }^{a}$ Age analysis using the single-aliquot regenerative-dose procedure of Murray and Wintle (2000) on 1-2 mm small-aliquots of quartz sand. Number of aliquots used in age calculation and number of aliquots analyzed in parentheses.

${ }^{\mathrm{b}}$ Equivalent dose $\left(\mathrm{D}_{\mathrm{E}}\right)$ calculated using the mean.

${ }^{\mathrm{c}}$ Overdispersion (OD) represents variance in $\mathrm{D}_{\mathrm{E}}$ data beyond measurement uncertainties, $\mathrm{OD}$.

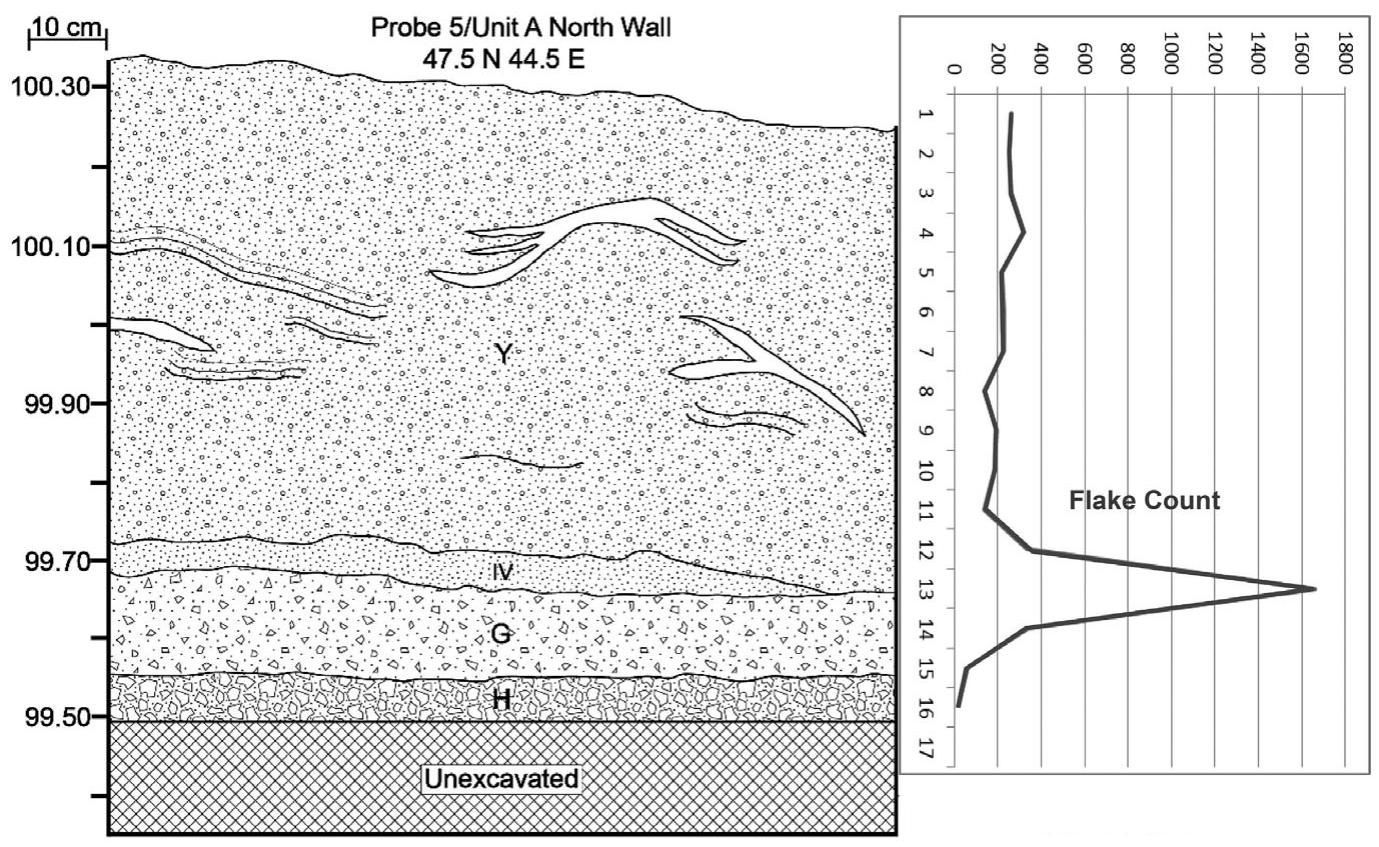

Figure 7. Stratigraphic profile and flake density by $5 \mathrm{~cm}$ level for Unit 5, located outside the dripline of Fort Rock Cave. The Stratum IV designation reflects the stratum as described by Kittleman (1968).

and a huge volume of animal bones from our excavations. A preliminary analysis has identified jackrabbit, marmot, and artiodactyl elements, including some elk-size bones, in the sample (Patrick O'Grady, personal communication 2016). Although well preserved, most bones are highly fragmented and were probably extensively processed. Edge-modified obsidian flakes are the most common tool type recovered during our work, followed by projectile points and point fragments. Most projectile points are foliate or WST types. We also recovered a Northern Sidenotched point base and several Rosegate points, indicating that people used the cave at least intermittently throughout the Holocene. Ground stone artifacts include metate fragments, a mano fragment, and anvil or abrading stones. Other notable artifacts include a pipe fragment and a possible bone point. Unfortunately, we recovered most artifacts from clearly disturbed deposits.

\section{Discussion and Conclusion}

People occupied Fort Rock Cave extensively during the early Holocene and potentially the terminal Pleistocene, a fact that explains the site's inclusion in reviews of TP/EH archaeology (Beck and Jones 1997; Jenkins, Connolly, and Aikens 2004). While most researchers dismiss Bedwell's (1973) claim of an exceptionally early occupation, the fact that the nearby Paisley Caves were first occupied $\sim 14,500$ cal B.P. compelled us to revisit the possibility that Fort Rock Cave might also hold clues about early visitors to 
the region. The primary goal of our return to Fort Rock Cave was to assess the integrity of remaining deposits and, potentially, to evaluate the context of Bedwell's earliest radiocarbon age. Based on a review of Bedwell's and Cressman's field notes, it appears that at least some of the reported ages are too old. In light of this, and the demonstrated unreliability of Gakushuin dates, we discount the earliest radiocarbon dates from Fort Rock Cave.

When we exclude the problematic dates, the reliable dates (e.g., those obtained on basketry) in aggregate reflect several trends in site occupation also suggested by the artifact assemblage:

(1) No clearly demonstrated occupation before 11,000 cal B.P.

(2) A substantial occupation dating to 10,500 9200 cal B.P. associated with the site's famous sandals and reliable, direct dates on fiber artifacts. Cressman's (1938) catalog lists 541 artifacts; approximately 38 percent appear to be from post-Mazama contexts and 62 percent from pre-Mazama contexts (Figures 2 and 3). Together, radiocarbon dates and projectile point types from the site suggest that the bulk of the Fort Rock Cave assemblage reflects TP/EH use of the site. Ethnographic sources from the region indicate that people wore woven fiber sandals in winter (Barrett 1910:255; Ray 1963:166; Spier 1930:208); their abundance at Fort Rock Cave suggests sustained occupation(s) throughout at least the cold season.

(3) Continued intermittent use throughout the Holocene. Projectile points recovered from the site include Large Side-notched, Elko and other dart points, Rosegate, and Desert Side-notched types. Two fragments of basketry, recovered from Fort Rock Cave by private individuals, also provide post-Mazama ages (Table 1).

We also conclude that: (1) damage to the deposits inside the cave was extensive, and, in our best judgment, thorough, following Cressman's initial visit; it is unlikely that intact deposits remain in most of the cave's interior; (2) there may be remaining, but limited, intact deposits outside of the cave or buried deep beneath the massive debris pile in front of the cave; (3) there is currently no evidence for an exceptionally early (i.e., Clovis or pre-Clovis) occupation at Fort Rock Cave; and (4) the upper lake-deposited gravels were probably exposed and only partially covered by eolian silt when people first occupied the cave. The lake-level history of Pluvial Lake Fort Rock is neither well understood nor well dated, and future work on this front will have implications for the archaeology of Fort Rock Cave, the nearby Connley Caves, and other sites in the Fort Rock Basin.

Bedwell's (1970, 1973) Northern Great Basin chronology, based on his research at Fort Rock and Connley Caves, relied on what for decades was the earliest and largest single set of terminal Pleistocene to late Holocene radiocarbon ages in the region, nearly all from the Gakushuin Laboratory. Their removal from the record would seemingly impact our assessment of the region's cultural chronology, but their absence is more than balanced by an ambitious program of excavation and survey in the Fort Rock and Chewaucan (Summer Lake) basins since 1989 (Jenkins, Connolly, and Aikens 2004; Jenkins et al. 2016), and the systematic dating of fiber artifacts (Connolly and Barker 2004; Connolly et al. 2016). To date, there are at least $475{ }^{14} \mathrm{C}$ determinations from this work, a majority being AMS dates with standard errors less than 100 years. While all are from cultural sites, not all are cultural (geochronological and paleontological samples) or duplicate dates experimentally run on chemical components of coprolites and sediments. Disregarding these, and Bedwell's 31 Gakushuin dates, we are left with 275 cultural dates on artifacts, charcoal, hearths, butchered bone/hide/fur, and human coprolites/hair ranging from $\sim 14,600$ cal B.P. to modern (Jenkins et al. 2016:144-170), on which the current regional chronology is based (Aikens et. al. 2011). While we have demonstrated that the stratigraphy and radiocarbon chronology of Fort Rock Cave do not contribute to our understanding of human colonization $\sim 15,000$ cal B.P., the site still figures prominently in this rich regional culture history.

Revisiting previously excavated sites is often a challenging proposition, especially when they were excavated before modern excavation and 
reporting standards were developed. Over the last 80 years, Fort Rock Cave has gone from being one of the most important archaeological sites in the northern Great Basin to a nearly devastated shell. The site's ruin is due in part to landowner management and decades of intensive looting; however, it is also the product of careless archaeology done with little regard for either future questioning or a conservation ethic. We hope that moving forward, old sites like Fort Rock Cave will remain important not only because of what was found but also because of the hard lessons learned regarding site preservation and management.

Acknowledgments. Funding for the project was provided by an Oregon Heritage Preserving Oregon Grant Program, the University of Oregon Museum of Natural \& Cultural History (UOMNCH) PaleoIndian Research Fund, the UOMNCH Edna English Trust, and the University of Nevada's (UNR) Great Basin Paleoindian Research Unit. Graduate students and/or research faculty from the University of Oregon, Oregon State University, Central Oregon Community College, Utah State University, and UNR volunteered time in our return visit to Fort Rock Cave. Bill Cannon and the Lakeview District of the Bureau of Land Management provided funding for several of the basketry dates. Chantel Saban translated the abstract into Spanish.

Data Availability Statement. Records and collections relating to the Fort Rock Cave excavations are at the University of Oregon Museum of Natural and Cultural History under accessions 60 (Cressman 1938) and 419 (Bedwell 1966-1967); records from our work are under 2302 (2015 fieldwork) and 2363 (2016 fieldwork).

\section{References Cited}

Aikens, C. Melvin, Thomas J. Connolly, and Dennis L. Jenkins

2011 Oregon Archaeology. Oregon State University Press, Corvallis.

Allison, Ira S.

1979 Pluvial Fort Rock Lake, Lake County, Oregon. Special Paper 7. Oregon Department of Geology and Mineral Industries, Portland.

Arnold, James R., and Willard F. Libby

1951 Radiocarbon Dates. Science 113:111-120.

Banks, William E., and Peter E. Wigand

2005 Reassessment of Radiocarbon Age Determinations for the Munkers Creek Phase. Plains Anthropologist 50:173-183.

Barrett, Samuel A.

1910 The Material Culture of the Klamath Lake and Modoc Indians of Northeastern California and Southern Oregon. University of California Publications in American Archaeology and Ethnology 5(4): 239-292.
Beck, Charlotte, and George T. Jones

1997 The Terminal Pleistocene/Early Holocene Archaeology of the Great Basin. Journal of World Prehistory 11:161-236.

Bedwell, Stephen F.

1967-1968 Field notebooks on file at the University of Oregon Museum of Natural \& Cultural History, Accession 419. Eugene.

1970 Prehistory and Environment of the Pluvial Fort Rock Lake Area of South Central Oregon. Ph.D. dissertation, Department of Anthropology, University of Oregon, Eugene.

1973 Fort Rock Basin: Prehistory and Environment. University of Oregon Books, Eugene.

Bedwell, Stephen F., and Luther S. Cressman

1971 Fort Rock Report: Prehistory and Environment of the Pluvial Fort Rock Lake Area of South-central Oregon. In Great Basin Anthropological Conference 1970: Selected Papers, edited by C. Melvin Aikens, pp. 1-25. Anthropological Papers 1, University of Oregon, Eugene.

Blakeslee, Donald J.

1994 Reassessment of Some Radiocarbon Dates from the Central Plains. Plains Anthropologist 39:203-210.

Bronk Ramsey, Christopher

2009 Bayesian Analysis of Radiocarbon Dates. Radiocarbon 51:337-360.

Bussey, Stanley D.

1967 Field notebook. On file at the University of Oregon Museum of Natural and Cultural History, Accession 419. Eugene.

Clark, Geoffrey, and Atholl Anderson

2001 The Age of the Yanuca Lapita Site, Viti Levu, Fiji. New Zealand Journal of Archaeology 22:15-30.

Connolly, Thomas J., and Pat Barker

2004 Basketry Chronology of the Early Holocene in the Northern Great Basin. In Early and Middle Holocene Archaeology of the Northern Great Basin, edited by Dennis L. Jenkins, Thomas J. Connolly, and C. Melvin Aikens, pp. 241-250. Anthropological Papers 62. University of Oregon, Eugene.

Connolly, Thomas J., and William J. Cannon

1999 Comments on "America's Oldest Basketry." Radiocarbon 41:309-313.

Connolly, Thomas J., Catherine S. Fowler, and William J. Cannon

1998 Radiocarbon Evidence Relating to Northern Great Basin Basketry Chronology. Journal of California and Great Basin Anthropology 20:88-100.

Connolly, Thomas J., Pat Barker, Catherine S. Fowler, Eugene M. Hattori, Dennis L. Jenkins, and William J. Cannon

2016 Getting Beyond the Point: Textiles of the Terminal Pleistocene/Early Holocene in the Northwestern Great Basin. American Antiquity 81:490-514.

Cressman, Luther S.

1938 Field notebook on file at the University of Oregon Museum of Natural \& Cultural History, Accession 60. Eugene.

1942 Archaeological Researches in the Northern Great Basin. Carnegie Institution of Washington, Washington, DC.

1951 Western Prehistory in the Light of Carbon 14 Dating. Southwestern Journal of Anthropology 7:289-313.

1977 Prehistory of the Far West: Homes of Vanished Peoples. University of Utah Press, Salt Lake City. 
1988 A Golden Journey: Memoirs of an Archaeologist. University of Utah Press, Salt Lake City.

Cressman, Luther S., and Howel Williams

1940 Early Man in Southcentral Oregon: Evidence from Stratified Sites. In Early Man in Oregon: Archaeological Studies in the Northern Great Basin, edited by Luther S. Cressman, Howel Williams, and Alex D. Krieger, pp. 53-78. Studies in Anthropology No. 3. University of Oregon, Eugene.

Fiedel, Stuart J.

2000 The Peopling of the New World: Present Evidence, New Theories, and Future Directions. Journal of Archaeological Research 8:39-103.

Forbes, Charles F.

1973 Pleistocene Shoreline Morphology of the Fort Rock Basin, Oregon. Unpublished Ph.D. dissertation, Department of Geography, University of Oregon, Eugene.

Freidel, Dorothy

1994 Paleolake Shorelines and Lake Level Chronology of the Fort Rock Basin, Oregon. In Archaeological Researches in the Northern Great Basin: Fort Rock Archaeology since Cressman, edited by C. Melvin Aikens and Dennis L. Jenkins, pp. 21-40. Anthropological Papers 50. University of Oregon, Eugene.

Gilbert, M. Thomas, Dennis L. Jenkins, Anders Götherstrom, Nuria Naveran, Juan J. Sanchez, Michael Hofreiter, Philip Francis Thompson, Jonas Binladen, Tomas F. G. Higham, Robert M. Yohe II, Robert Parr, Linda Scott Cummings, and Eske Willerslev

2008 DNA from Pre-Clovis Human Coprolites in Oregon, North America. Science 320:786-789.

Haynes, C. Vance Jr.

1992 Contributions of Radiocarbon Dating to the Geochronology of the Peopling of the New World. In Radiocarbon after Four Decades, edited by R. Ervin Taylor, Austin Long, and Renee S. Kra, pp. 355374. Springer-Verlag, New York.

Hockett, Bryan, Ted Goebel, and Kelly Graf

2008 The Early Peopling of the Great Basin. In The Great Basin: People and Place in Ancient Times, edited by Catherine S. Fowler and Don D. Fowler, pp. 33-43. School for Advanced Research, Santa Fe, New Mexico.

Jenkins, Dennis L., Thomas J. Connolly, and C. Melvin Aikens

2004 Early and Middle Holocene Archaeology in the Northern Great Basin: Dynamic Natural and Cultural Ecologies. In Early and Middle Holocene Archaeology in the Northern Great Basin, edited by Dennis L. Jenkins, Thomas J. Connolly, and C. Melvin Aikens, pp.120. Anthropological Papers 62. University of Oregon, Eugene.

Jenkins, Dennis L., Loren G. Davis, Thomas W. Stafford Jr., Paula F. Campos, Bryan Hockett, George T. Jones, Linda Scott Cummings, Chad Yost, Thomas J. Connolly, Robert M. Yohe II, Summer C. Gibbons, Maanasa Raghavan, Morten Rasmussen, Johanna L. A. Paijmans, Michael Hofreiter, Brian M. Kemp, Jodi Lynn Barta, Cara Monroe, M. Thomas P. Gilbert, and Eske Willerslev

2012 Clovis Age Western Stemmed Projectile Points and Human Coprolites at the Paisley Caves. Science 337:223-228.

Jenkins, Dennis L., Loren G. Davis, Thomas W. Stafford Jr., Paula F. Campos, Thomas J. Connolly, Linda S. Cummings, Michael Hofreiter, Bryan Hockett, Katelyn McDonough, Ian Luthe, Patrick W. O'Grady,
Karl J. Reinhard, Mark E. Swisher, Frances White, Bonnie Yates, Robert M. Yohe II, Chad Yost, and Eske Willerslev

2013 Geochronology, Archaeological Context, and DNA at the Paisley Caves. In Paleoamerican Odyssey, edited by Kelly E. Graf, Caroline V. Ketron, and Michael R. Waters, pp. 485-510. Center for the Study of First Americans, College Station, Texas.

Jenkins, Dennis L., Loren G. Davis, Thomas W. Stafford Jr., Thomas J. Connolly, George T. Jones, Michael Rondeau, Linda Scott Cummings, Bryan Hockett, Katelyn McDonough, Patrick W. O'Grady, Karl J. Reinhard, Mark E. Swisher, Frances White, Robert M. Yohe II, Chad Yost, and Eske Willerslev

2016 Younger Dryas Archaeology and Human Experience at the Paisley Caves in the Northern Great Basin. In Stones, Bones, and Profiles: Exploring Archaeological Context, Early American Hunter-Gatherers, and Bison, edited by Marcel Kornfeld and Bruce B. Huckell, pp. 127-205. University Press of Colorado, Boulder.

Jenkins, Dennis L., Michael S. Droz, and Thomas J. Connolly

2004 Geoarchaeology of Wetland Settings in the Fort Rock Basin, South Central Oregon. In Early and Middle Holocene Archaeology in the Northern Great Basin, edited by Dennis L. Jenkins, Thomas J. Connolly, and C. Melvin Aikens, pp. 3152. Anthropological Papers 62. University of Oregon, Eugene.

Kittleman, Lawrence. R

1968 Geologic Stratigraphy of the Fort Rock Cave Site (35LK1), Lake County, Oregon. Memo to Luther S. Cressman. On file at the Oregon State Museum of Anthropology, University of Oregon, Accession 419. Eugene.

Krieger, Alex D.

1944 Review of Archaeological Researches in the Northern Great Basin, edited by L. S. Cressman, Frank C. Baker, Paul S. Conger, Henry P. Hanson, and Robert F. Heizer. American Antiquity 9:351-359.

Lawrence, Robert D.

1976 Strike-Slip Faulting Terminates the Basin and Range Province in Oregon. Geological Society of America Bulletin 87:846-850.

Martin, Paul S., George I. Quimby, and Donald Collier

1947 Indians before Columbus: Twenty Thousand Years of North American History Revealed by Archaeology. University of Chicago Press, Chicago, Illinois.

Maschner, Herbert D. G.

2004 Redating the Hot Springs Village Site in Port Moller, Alaska. Alaska Journal of Anthropology 2:100-116.

Murray, Andrew S., and Ann C. Wintle

2000 Luminescence Dating of Quartz Using an Improved Single Aliquot Regenerative-Dose Protocol. Radiation Measurements 32:57-73.

Ollivier, Aaron P

2016 Evaluating Gaps in the Radiocarbon Sequences of Northwestern Great Basin Sandals. Unpublished Master's thesis, Department of Anthropology, University of Nevada, Reno.

Perry, Walter J.

1937 August 22 letter to Luther Cressman. On file at the University of Oregon Museum of Natural and Cultural History, Accession 100BP. Eugene.

Ray, Verne $\mathrm{R}$

1963 Primitive Pragmatists: The Modoc Indians of Northern California. University of Washington Press, Seattle. 
Reimer, Paula J., Edouard Bard, Alex Bayliss, J. Warren Beck, Paul G. Blackwell, Christopher Bronk Ramsey, Caitlin E. Buck, Hai Cheng, R. Lawrence Edwards, Michael Friedrich, Pieter M Grootes, Thomas P. Guilderson, Haflidi Haflidason, Irka Hajdas, Christine Hatté, Timothy J. Heaton, Dirk L. Hoffmann, Alan G. Hogg, Konrad A. Hughen, K. Felix Kaiser, Bernd Kromer, Sturt W. Manning, $\mathrm{Mu}$ Niu, Ron W. Reimer, David A. Richards, E. Marian Scott, John R. Southon, Richard A. Staff, Christian S. M. Turney, and Johannes van der Plicht

2013 IntCal13 and Marine13 Radiocarbon Age Calibration Curves 0-50,000 Years Cal B.P. Radiocarbon 55:1869-1887.

Rittenour, Tammy

2016 Final Luminescence Report: Fort Rock Cave. Unpublished manuscript on file, Utah State University Luminescence Laboratory, Logan, Utah.

Roberts, Frank H. H., Jr.

1940 Developments in the Problem of the North American Paleo-Indian. In Essays in Historical Anthropology of North America, pp. 51-116. Smithsonian Miscellaneous Collections Vol. 100. Smithsonian Institution, Washington, DC.

Spier, Leslie

1930 Klamath Ethnography. University of California Publications in American Archaeology and Ethnology 30:1-338.

Spriggs, Matthew

1990 Dating Lapita: Another View. In Lapita DeSign, Fonn and Composition: Proceedings of the Lapita Design Workshop, Canberra, 1988, edited by
Matthew Spriggs, pp. 6-27. Occasional Papers in Prehistory 19. Department of Prehistory, Research School of Pacific Studies, Australia National University, Canberra.

Steward, Julian H.

1940 Native Cultures of the Intermontane (Great Basin) Area. In Essays in Historical Anthropology of North America, pp. 445-502. Smithsonian Miscellaneous Collections Vol. 100. Smithsonian Institution, Washington, DC.

Walker, George W., Norman W. Peterson, and Robert C. Greene

1967 Reconnaissance Geologic Map of the East Half of the Crescent Quadrangle, Lake, Deschutes, and Crook Counties, Oregon. Miscellaneous Geologic Investigations Map I-493. U.S. Geological Survey, Washington, DC.

Waters, Michael R., and Thomas W. Stafford Jr.

2007 Redefining the Age of Clovis: Implications for the Peopling of the Americas. Science 315:1122-1126.

\section{Note}

1. All radiocarbon dates were calibrated using $\mathrm{OxCal} 4.2$ online program (Bronk Ramsey 2009) with IntCal13 curve (Reimer et al. 2013) and presented as $2 \sigma$ calendar age ranges unless otherwise noted.

Submitted October 31, 2016; Revised January 18, 2017;

Accepted January 29, 2017 